\title{
Application of GIS tools for Leça River Basin soil erosion (Northern Portugal) evaluation
}

\author{
F. Taveira-Pinto 1 , S. Petan ${ }^{2}$, M. Mikos ${ }^{2} \&$ J. Pais-Barbosa ${ }^{3}$ \\ ${ }^{1}$ University of Porto, Faculty of Engineering, Department of Civil Engineering, \\ Hydraulics, Water Resources and Environment Division, Porto, Portugal \\ ${ }^{2}$ University of Ljubljana, Faculty of Civil and Geodetic Engineering, \\ Chair of Hydrology and Hydraulic Engineering, Ljubljana, Slovenia \\ ${ }^{3}$ University of Porto, Faculty of Sciences, Geo-Spatial Sciences Research Centre, \\ Porto, Portugal
}

\begin{abstract}
Applying GIS-based RUSLE methodology, the main goal of the present study is to forecast soil loss and identify areas of high erosion potential in the Leça River Basin, located in Northern Portugal. The rasterlayered model was structured in ArcGIS for two different scales: grid cell sizes of 10 and 30 meters. The average annual soil loss in Leça River Basin was estimated at $33.2 \mathrm{t} / \mathrm{ha}$, which produces a sediment yield of $52000 \mathrm{~m}^{3} /$ year. It was also estimated that $31 \%$ of the basin could be classified as areas of moderate erosion risk with annual soil loss of between 12 and $50 \mathrm{t} / \mathrm{ha}, 18 \%$ classified as areas of severe erosion risk and $51 \%$ as areas of low erosion risk.
\end{abstract}

Keywords: RUSLE, modelling, GIS, soil erosion, basin.

\section{Introduction}

Soil erosion is generally associated with the loss of arable soil and pollution of aquatic ecosystems, which may further unbalance the environment on a wider scale. However, this process is very important to a positive sediment balance in coastal zone dynamic equilibriums. Thus, precise information about soil erosion processes is of major importance for any attempt at managing environmental degradation. Measurements of soil erosion and sediment yields are relatively scarce and limited to small scales.

In the last few decades many new mathematical models have been developed to increase knowledge about soil erosion processes, and they are used for soil 
loss and sediment yield predictions on small or basin scales. Basically, the spatially-distributed soil erosion models available nowadays are divided into two groups.

The first group is formed by models that are based on measurements on small scales, extrapolated to large scales [1], such as RUSLE2 [2], WATEM [3], AnnAGNPS [4] and AGNPS-UM [5].

The second group includes models that are based on physical principles. EUROSEM [6], EROSION-3D [7], LISEM [8], WEPP [9] and SWAT [10] are among the process models that are under continuous development.

The GIS-based model presented in this paper takes the advantage of the simplicity of RUSLE and the parameter availability while modelling soil erosion in GIS. This methodology was used for soil loss prediction and identifying areas with high erosion potential in the Leça River Basin of northern Portugal. The methodology presented in this work for soil loss estimation and identifying areas with high potential erosion had never been applied to the basin under study.

\subsection{Study area}

On its flow towards the Atlantic Ocean, Leça River drains an area of $187 \mathrm{~km}^{2}$ (fig. 1). Between the $1950 / 51$ and $1985 / 86$ hydrological years, the watershed received on average $1311 \mathrm{~mm}$ of precipitation per year [11]. The average precipitation amounts in the western, coastal areas of the watershed are around $1200 \mathrm{~mm}$, and approximately $1600 \mathrm{~mm}$ in the eastern parts- the highest spots of the basin (up to 550 m.a.s.1.). The majority of the precipitation falls during the winter months, between November and March.

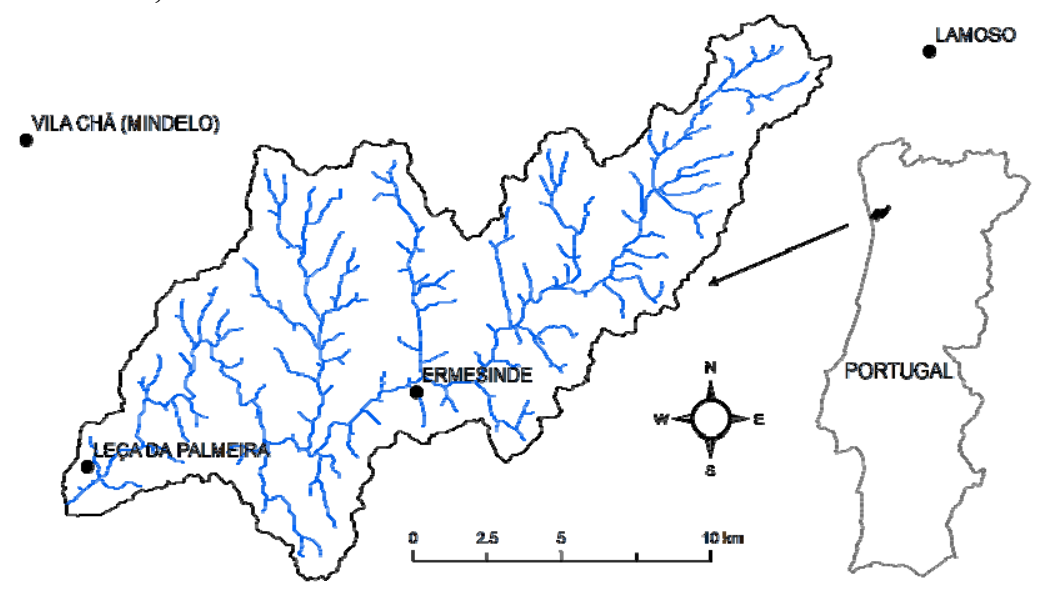

Figure 1: Leça River basin and the meteorological station locations.

The River Leça mouth is in the Leixões Harbour basin, an important shipping harbour. For security and operational reasons this facility often performs dredging works to maintain depth. The quantification of sediment volume is a key issue in Leixões Harbour basin sediment management. 


\section{Method}

The Universal Soil Loss Equation USLE [12] and the revised version - RUSLE [13] were designed to predict long-term average annual soil loss, $A$. Both models are represented by the equation involving six factors:

$$
A=R \cdot K \cdot L \cdot S \cdot C \cdot P
$$

where $R$ is the average rainfall-runoff erosivity factor $\left(\mathrm{MJ} \mathrm{ha}^{-1} \mathrm{~mm} \mathrm{~h}^{-1}\right), K$ the soil erodibility factor $\left(\mathrm{t} \mathrm{MJ}^{-1} \mathrm{~h} \mathrm{~mm}^{-1}\right), L$ the slope length factor, $S$ the slope steepness factor, $C$ the cover-management factor and $P$ the support practice factor. The four dimensionless factors $(L, S, C$ and $P)$ are formatted as ratios between the soil loss on the specific site and the soil loss on the unit USLE erosion plot $(22.1 \mathrm{~m}$ long on a $9 \%$ slope gradient, without vegetation, cultivated up and down-slope), on which measurements the (R)USLE methodology is based. The RUSLE model was structured in ArcGIS 9.2 for two grid cell sizes of 10 and $30 \mathrm{~m}$.

\subsection{Rainfall-runoff erosivity $R$ factor}

The $R$ factor is defined as the average annual sum of the products of the rainfall (erosive events) kinetic energy $E$ and the maximum 30-minute rainfall intensity $I_{30}$. In our case, the $R$ factor was calculated from the available long-term daily precipitation data using the equation developed from rainfall measurements taken in the Algarve, southern Portugal, between October 1992 and March 1997, and introduced by Loureiro and Coutinho [14].

$$
E I_{30 \text { month }}=7.05 \cdot \text { rain }_{10}-88.92 \cdot \text { days }_{10}
$$

where $E I_{30 \text { month }}$ represents the monthly $R$ factor, rain $_{10}$ is the monthly rainfall sum for days with rainfall $\geq 10 \mathrm{~mm}$ and days ${ }_{10}$ monthly number of days with rainfall $\geq 10 \mathrm{~mm}$. The average annual $R$ factor was calculated for 4 meteorological stations, two of them within the river basin, as the sum of monthly averages for the 12-year period between 1983 and 1994. The few negative $R$ factor values for the months with low or no rainfall were set to zero.

\subsection{Soil erodibility $\mathrm{K}$ factor and cover-management $\mathrm{C}$ factor}

Only one soil type - humiccambisol, was identified on the soil map of Portugal for the whole area of the Leça River basin. A soil erodibility $K$ factor of 0.032 was chosen according to the Portuguese instructions for use of USLE [15]. The same reference was used for deriving the $C$ factor from relatively coarse (1:100.000) CORINE land cover data 1990 (CLC90) and from the more detailed (1:25.000) national land use map COS'90.

\subsection{Topographic $L$ and $S$ factors}

Vector topographic data with $10 \mathrm{~m}$ distance was used to derive two digital elevation models (DEM) at $10 \mathrm{~m}$ and $30 \mathrm{~m}$ resolution. Depressionless (filled) DEMs were used to calculate the values for slope, flow direction, flow accumulation and flow length for each of the raster cells. These values were necessary for deriving the topographic factors. The $L$ factor was calculated using 
3 methods. First implemented was the equation suggested by Desmet and Govers [16], cited in [1], which has been commonly used in soil erosion GIS models (like WATEM, [3]; AGNPS-UM, [5]):

$$
L_{i, j}=\frac{\left(A_{i, j-i n}+D^{2}\right)^{m+1}-A_{i, j-i n}^{m+1}}{D^{m+2} \cdot x_{i, j}^{m} \cdot 22.13^{m}}
$$

where $A_{i, j-i n}$ is the runoff contributing area to the cell with coordinates (i,j), $D$ is cell size in metres, $x$ is cell orientation factor (usually neglected) and $m$ is slopelength exponent. First (method 1, fig. 5, left), the $m$ exponent was calculated from $\beta$, the ratio of rill and interrill erosion as suggested in the RUSLE user guide [13]:

$$
\beta=\frac{m=\frac{\beta}{\beta+1}}{0.0896 \cdot\left[3.0 \cdot(\sin \theta)^{0.8}+0.56\right]}
$$

where $\theta$ is the slope angle. Later (method 2, fig. 5, right), the $m$ exponent was assumed as a constant value of 0.4 , which is consistent with the approach of Moore and Burch [17].

The $L$ factor was also derived using the standard procedure of (R)USLE (method 3):

$$
L=\left(\frac{\lambda}{22.13}\right)^{m}
$$

where $\lambda$ is the slope length, estimated as the sum of the upstream length $\left(L_{u}\right)$ of the longest flow path within the flow accumulation area of each cell plus half of the grid cell size $(\mathrm{D} / 2)$. Later, maps of the limited values for the $L$ factor were also derived for the three methods described. The $L$ factor cell values were limited with the maximum value for slope length $\lambda$, as suggested in the RUSLE user guide (1000 ft or approximately $300 \mathrm{~m}$ ).

The slope steepness $S$ factor was calculated from the slope angle according to the RUSLE procedure [13]:

$$
\begin{array}{ll}
S=10.8 \sin \theta+0.03 & \text { for slopes }<9 \%, \\
S=16.8 \sin \theta-0.50 & \text { for slopes } \geq 9 \%
\end{array}
$$

\subsection{Support practice $P$ factor}

Supporting land management practices such as contouring, strip cropping and terracing reduce the soil erosion of disturbed lands [18]. As a rule, for areas without supporting practices, or as in our case where information about supporting practices in the Leça River basin was unavailable, the $P$ factor is set to 1 for the whole area. In such cases the model calculates potential instead of actual soil loss. 


\subsection{Erosion risk classes}

After the calculation of soil loss $A$ the values were classified into the six erosion risk classes shown in table 1, as applied by Irvem et al. [19], which was suitable for mapping the results of the model.

Table 1: $\quad$ Erosion risk classes after Irvem et al. [19].

\begin{tabular}{|c|c|c|c|c|c|c|}
\hline $\begin{array}{c}\text { Annual } \\
\text { soil loss A } \\
{[\mathrm{t} / \mathrm{ha}]}\end{array}$ & $<5$ & $5-12$ & $12-50$ & $\begin{array}{c}50- \\
100\end{array}$ & $\begin{array}{c}100- \\
200\end{array}$ & $>200$ \\
\hline $\begin{array}{c}\text { Erosion } \\
\text { risk class }\end{array}$ & $\begin{array}{c}\text { Very } \\
\text { low }\end{array}$ & Low & Moderate & Severe & $\begin{array}{c}\text { Very } \\
\text { severe }\end{array}$ & $\begin{array}{c}\text { Extremely } \\
\text { severe }\end{array}$ \\
\hline
\end{tabular}

\subsection{Sediment delivery ratio (SDR)}

The (R)USLE model calculates soil loss $A$ and does not consider soil deposition. To estimate the sediment delivered in the stream channels - sediment yield $Y$, a sediment delivery ratio $S D R$ should be taken into account $(Y=A \cdot S D R)$. The sediment delivery ratio of a certain watershed is influenced by many geomorphological, hydrological, environmental and watershed factors [20]. Some models, such as AnnAGNPS, WATEM and RUSLE2, use the USLE model coupled with a sediment transport capacity model to estimate sediment delivery [1]. In our case the $S D R$ was simply estimated from the drainage area $A_{d}$ using three $S D R$ curves, all formulated as:

$$
S D R=a \cdot A_{d}^{-b}
$$

where $a$ and $b$ are coefficients proposed by different authors, as given in table 2 . The average value from the three SDR curves (0.217) was considered as the SDR value for the Leça River basin.

Table 2: $\quad$ Sediment delivery curves, as cited in [21], and SDR values for the Leça River basin.

\begin{tabular}{|c|c|c|c|}
\hline Coefficient & Vanoni (1975) & Boyce (1975) & USDA (1979) \\
\hline $\mathrm{a}$ & 0.473 & 0.413 & 0.566 \\
\hline $\mathrm{b}$ & 0.125 & 0.3 & 0.11 \\
\hline
\end{tabular}

\section{Results}

\subsection{Erosion factors, $R, C, L$ and $S$}

The spatial distribution of the $R$ factor was derived using the IDW (Inverse Distance Weighed) interpolation method (fig. 2).

During the process of assigning the cover-management $\mathrm{C}$ factor, 18 and 91 different CLC90 and COS'90 land use types were identified respectively, with values ranging from 0 to 0.5 (fig. 3). Significant land cover differences were 


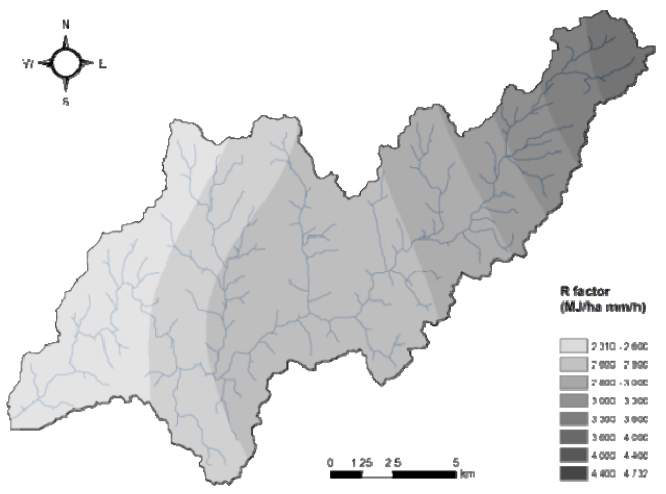

Figure 2: $\quad$ Average annual rainfall-runoff erosivity $R$ factor $(30 \mathrm{~m}$ grid cell size) of the Leça River basin for the period between 1983 and 1994.

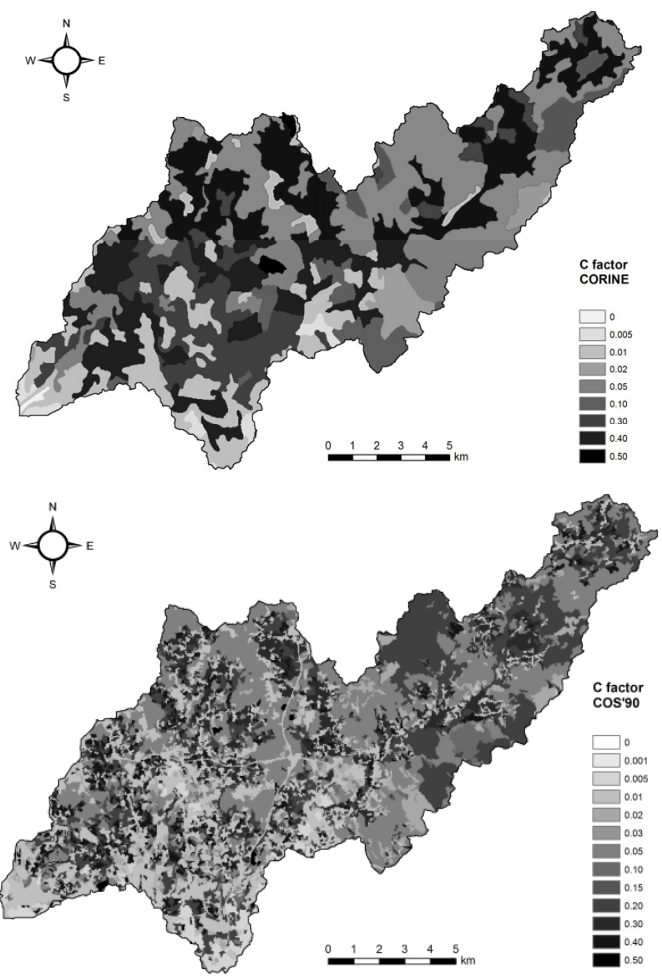

Figure 3: Cover-management $\mathrm{C}$ factor (30 $\mathrm{m}$ grid cell size) estimated from: top - the coarser CLC90 data and bottom - the finer COS'90 land use data. 
noticed between the two land use/cover data sources. According to the newer COS'90 land use data, the percentage of agricultural areas dropped by $36 \%$ on account of increased forested areas and, especially, artificial surfaces. As the C factor values for the latter land uses are considerably lower than for agricultural areas, the average $\mathrm{C}$ factor value dropped consecutively by $38 \%$, from 0.19 (CLC90) to 0.12 (COS'90). The spatial distribution of the topographic factors $\mathrm{L}$ and $\mathrm{S}$ is shown in figs. 4 and 5.

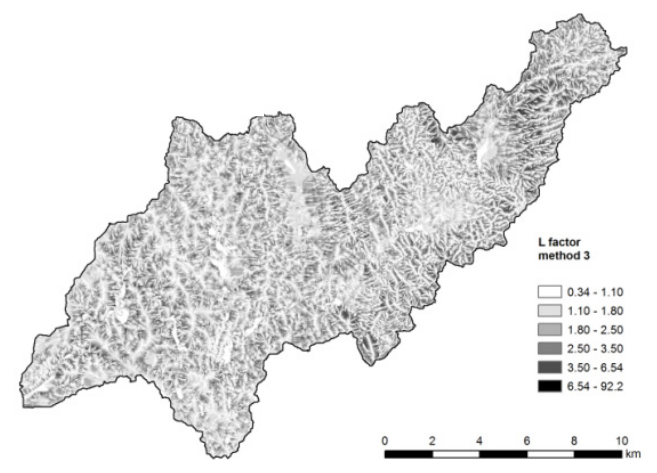

Figure 4: $\quad$ Slope length $\mathrm{L}$ factor $(10 \mathrm{~m}$ grid cell size) as calculated with method 3 (equation equations (6), (4) and (5)). The last class (black colour) represents the cells where the $\mathrm{L}$ factor was later limited (according to the maximum value for slope length $\lambda-$ $300 \mathrm{~m}$ ) to the lowest value of the same class range.

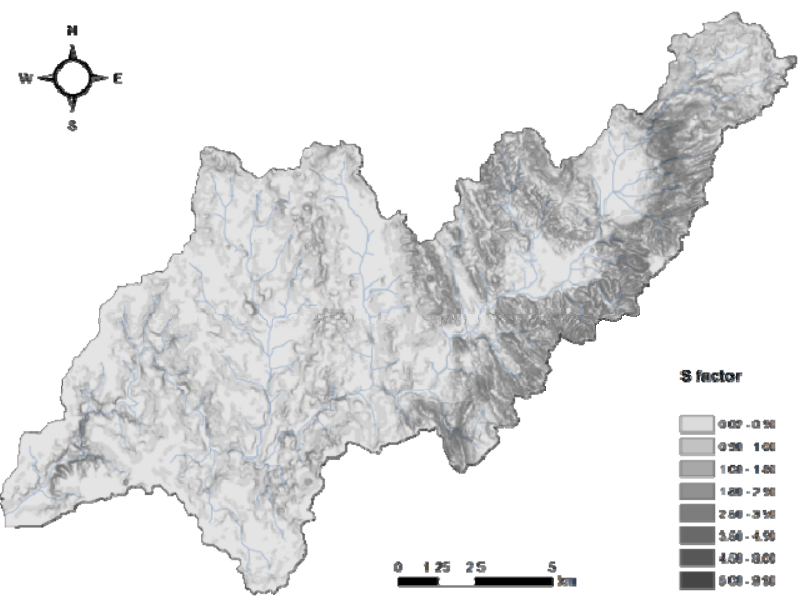

Figure 5: Slope steepness $\mathrm{S}$ factor (10 $\mathrm{m}$ grid cell size) of the Leça River basin. 


\subsection{Soil loss A}

Six soil loss $A$ maps were delivered for each grid cell size according to the three methods applied for calculation of the $L$ factor and the limited $L$ factor values. The $C$ factor was estimated from the CLC90 data. A brief summary of the results is presented in fig. 6 .

The mean annual soil loss value $A$ and also its maximum values were less affected by the limited $L$ factor when the standard RUSLE procedure for $L$ factor estimation was implemented (method 3 ). Limiting the $L$ factor caused dropping of the mean $A$ value by $3 \%$ and $8 \%$ in the $10 \mathrm{~m}$ and $30 \mathrm{~m}$ model grid scale, respectively. When the two methods that originate from equation (3) were applied (method 1 and 2), value $A$ drops amounted to between $24 \%$ and $44 \%$ of the total. The effect of limiting the $L$ factor is also well seen in fig. 5 , where the limiting process had the lowest impact when method 3 was applied. This method was therefore recognised as the one that gives the most probable results, and so the limited $L$ factor values from method 3 accompanied with the $C$ factor estimated from the COS'90 data were used to calculate another soil loss $A$ map (method 3_lim*) shown in fig. 7.

The results of the last three methods (as listed in fig. 6) showed that the coarser model in comparison with the finer one returned $9 \%, 3 \%$ and $2 \%$ greater average soil loss $A$ for method 3, 3_lim and 3_lim*, respectively.

The maximum $A$ values of the coarser model were $15 \%$ to $25 \%$ lower than the finer model, which was expected due to the effect of the greater cell size averaging. Small differences are also noticeable in the presence of the erosion risk classes: the coarser model gives a slightly higher percentage of the severe erosion risk classes (above $50 \mathrm{t} / \mathrm{ha}$ of annual soil loss).

\begin{tabular}{|c|c|c|c|c|c|c|c|c|c|c|}
\hline \multirow{2}{*}{ method } & \multirow{2}{*}{ cell size } & \multicolumn{3}{|c|}{ annual soil loss $A$ [t/ha] } & \multicolumn{6}{|c|}{ area [\%] per erosion risk class [t/ha] } \\
\hline & & mean & STDV & max. value & $<5$ & $5-12$ & $12-50$ & $50-100$ & $100-200$ & $>200$ \\
\hline \multirow{2}{*}{1} & 10 & 73.9 & 938 & 713531 & 25.1 & 12.6 & 32.0 & 14.9 & 8.8 & 6.6 \\
\hline & 30 & 82.6 & 807 & 202632 & 24.3 & 12.1 & 31.3 & 15.3 & 9.4 & 7.5 \\
\hline \multirow{2}{*}{ 1_lim } & 10 & 47.9 & 89.2 & 2143 & 26.0 & 13.3 & 33.6 & 15.0 & 7.7 & 4.4 \\
\hline & 30 & 46.5 & 83.2 & 1510 & 25.9 & 13.2 & 34.1 & 15.2 & 7.6 & 4.1 \\
\hline \multirow{2}{*}{2} & 10 & 50.5 & 129 & 26165 & 24.0 & 12.8 & 35.2 & 16.1 & 7.7 & 4.2 \\
\hline & 30 & 56.8 & 145 & 12532 & 22.6 & 12.4 & 34.8 & 16.4 & 8.8 & 5.1 \\
\hline \multirow{2}{*}{ 2_lim } & 10 & 37.3 & 55.8 & 977 & 25.6 & 13.2 & 38.0 & 15.3 & 5.7 & 2.2 \\
\hline & 30 & 36.0 & 51.7 & 728 & 25.0 & 13.5 & 38.9 & 15.1 & 5.7 & 1.9 \\
\hline \multirow{2}{*}{3} & 10 & 36.6 & 72.9 & 9297 & 29.0 & 15.2 & 35.5 & 12.2 & 5.6 & 2.6 \\
\hline & 30 & 39.8 & 85.5 & 7875 & 28.1 & 14.8 & 35.1 & 12.9 & 6.0 & 3.0 \\
\hline \multirow{2}{*}{ 3_lim } & 10 & 35.4 & 65.4 & 1943 & 29.1 & 15.3 & 35.7 & 12.1 & 5.4 & 2.4 \\
\hline & 30 & 36.5 & 66.9 & 1440 & 28.5 & 15.2 & 35.6 & 12.6 & 5.7 & 2.5 \\
\hline \multirow{2}{*}{ 3_lim* } & 10 & 30.1 & 66.0 & 1518 & 42.5 & 15.4 & 26.8 & 7.9 & 4.5 & 2.9 \\
\hline & 30 & 30.7 & 66.7 & 1180 & 41.7 & 15.3 & 27.3 & 8.3 & 4.6 & 2.8 \\
\hline
\end{tabular}

Figure 6: Soil loss and erosion risk classes according to the different methods for L factor calculation. The methods used when the limited L factor values were calculated are additionally marked with " lim". The C factor was estimated from the CLC90 data for all methods except for the method marked as 3 lim*, where COS'90 data was used. 

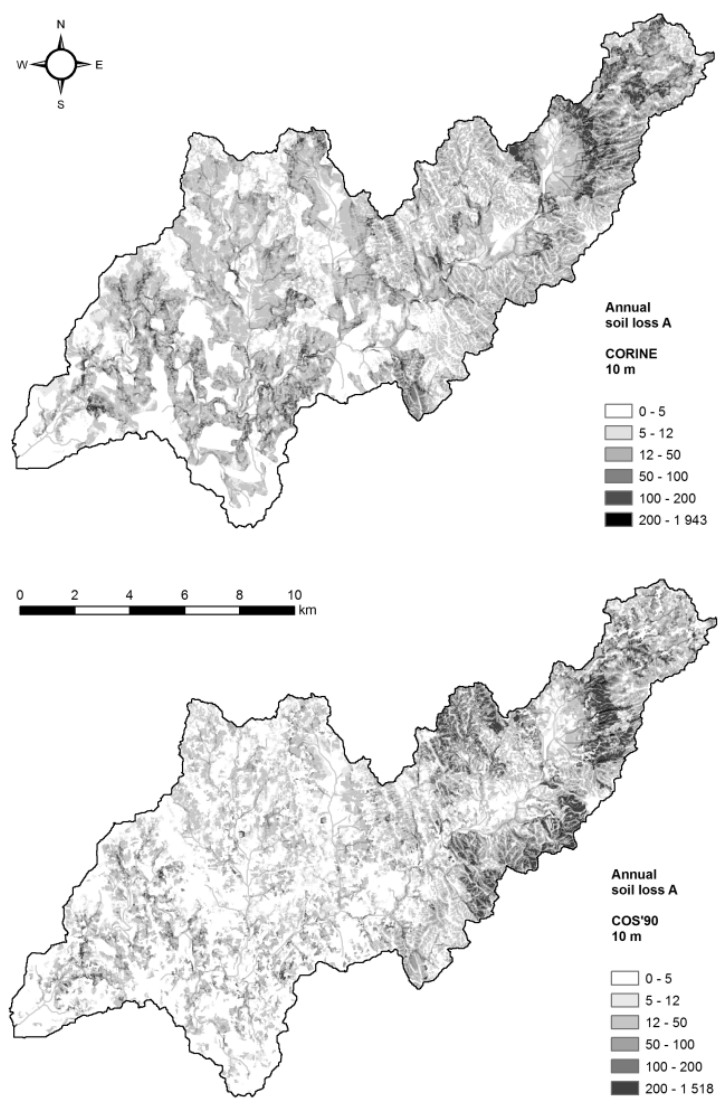

Figure 7: Annual soil loss $\mathrm{A}$ at $10 \mathrm{~m}$ grid cell size considering CLC90 (method 3_lim) - top, and COS'90 land use data (method 3_lim*) - bottom.

The model considering COS'90 data calculated $15 \%$ and $16 \%$ lower average annual soil losses than the model which incorporates CLC90 coverage, for the 10 and $30 \mathrm{~m}$ grid cell sizes respectively.

The lower relative drop of the average annual soil loss in comparison with the $\mathrm{C}$ factor drop is explained by the different spatial distribution of $\mathrm{C}$ factor values across the river basin (fig. 3).

The lower average $C$ factor originating from the COS'90 land use data became evident when the erosion risk classes were grouped: the sum of the three "severe" classes decreased to $20 \%$ for CLC90 and 15\% for COS'90 data, while the sum of the two "low" erosion risk classes increased on account of the "severe" and the "moderate" class, from 44\% to 57\% for CLC90 and COS'90 data, respectively (fig. 8). Considering the results (10 and $30 \mathrm{~m}$ models) returned by method 3 for both land use data sources (CLC90 and COS'90) the average annual soil loss $A$ in the Leça River basin is estimated at $33.2 \mathrm{t} / \mathrm{ha}$. Such a soil loss rate gives a sediment yield of approximately 135,000 tons or $52,000 \mathrm{~m}^{3}$ 
considering a sediment delivery ratio of 0.217 , calculated as the average of the values returned by the three sediment delivery curves (equation (9), table 2) and the total drainage area of the basin.

\section{Discussion and conclusions}

An average annual soil loss $A$ for Leça River basin was estimated using a GISbased RUSLE model on two grid scale sizes, 10 and 30 meters. The model included a 12-year series of daily rainfall data from $(1983$ - 1994) from 4 meteorological stations for rainfall-runoff erosivity $R$ factor estimation. The average $\mathrm{R}$ factor for the whole river basin area is estimated to be $2992 \mathrm{MJ} / \mathrm{ha}$ $\mathrm{mm} / \mathrm{h}$. The slope steepness $\mathrm{S}$ factor was derived according to the standard RUSLE procedure, while the slope length $L$ factor was calculated by implementation of three methods: the first and second originating from the equation proposed by Desmet and Govers [16] and the third as suggested in the standard (R)USLE procedure.

The soil erodibility $K$ factor and the soil-management $C$ factor were derived from the national soil map and the land use data (CLC90 and COS'90 respectively), according to the Portuguese instructions for use of USLE [15]. In the Leça River basin a single soil type was recognised - humiccambisol, with a soil erodibility $\mathrm{K}$ factor of 0.032 . The support practice $\mathrm{P}$ factor was set to 1 for the whole basin area. The performances of the implemented methods for $L$ factor estimation were analysed and the standard (R)USLE procedure was chosen (method 3 lim) as the one that gives the most probable results.

The areas with the highest potential erosion are found on the western and north-western part of the basin where forested areas predominate, and also on the steep banks and hill slopes above the river streams in the lower western sections. On average, while considering both land use data sources and grid cell sizes, $31 \%$ of the basin can be classified as areas of moderate erosion risk (annual soi loss of $12-50 \mathrm{t} / \mathrm{ha}$ ), $18 \%$ as severe or above moderate and $51 \%$ as low or below the moderate erosion risk class.

The average annual soil loss $\mathrm{A}$ in Leça River basin is $33.2 \mathrm{t} / \mathrm{ha}$, considering the most probable results from both land use data sources (CLC90 and COS'90)

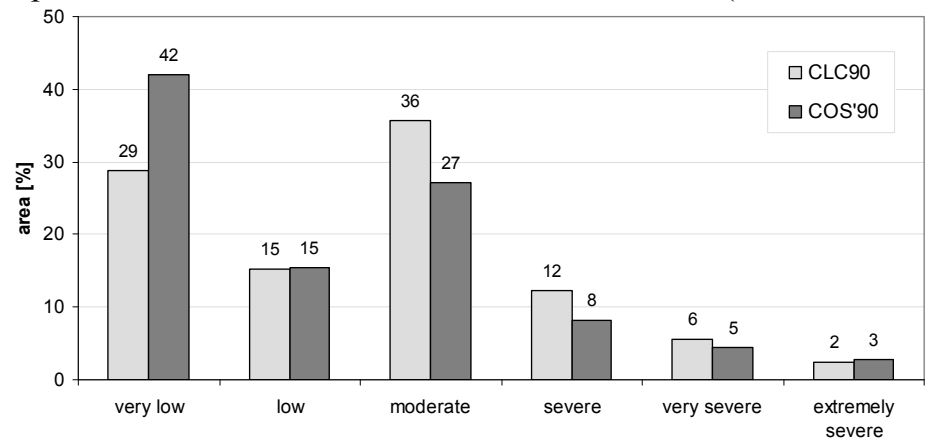

Figure 8: Classification of soil loss A into erosion risk classes for 3_lim (CLC90) and 3 lim* (COS'90) methods. 
and grid cell sizes. Such a soil loss rate seems to be rather overestimated and on the high end of the mean actual soil erosion rates in Europe. Considering the average sediment delivery ratio of 0.217 , a sediment yield of approximately 135000 tons or $52000 \mathrm{~m}^{3} /$ year is expected at the outlet of the basin.

The GIS-based model had few imperfections. The rainfall-runoff erosivity $R$ factor was estimated using the available daily rainfall data and the empirical equation for monthly $R$ factor estimation in the Algarve region of southern Portugal. This could be improved if short-term rainfall intensities were available, so the $R$ factor can be estimated from the standard RUSLE procedure. Collecting the necessary data about soil-supporting practices in the river basin and involving them in the model would also improve the soil loss estimation. The sediment yield $Y$ was estimated from simply-formulated sediment delivery curves that consider only the basin's drainage area. Coupling the model with a sediment transport capacity model would improve the sediment yield estimation. Finally, after all these improvements are done, verification of the model with suspended sediment measurements data would enhance the model predictions.

\section{References}

[1] Kinnell, P.I.A. (2008) Sediment delivery from hillslopes and the Universal Soil Loss Equation: some perceptions and misconceptions. Hydrol. Processes22, 3168-3175.

[2] Foster, G.R. (2005) Revised Universal Soil Loss Equation, version 2 (RUSLE2), Science Documentation, draft. USDA-Agricultural Research Service Washington, D.C., USA.

[3] van Oost, K., Govers, G., Desmet, P. (2000) Evaluating the effect of changes in landscape structure on soil erosion by water and tillage. Landscape Ecol.15, 577-589.

[4] Bingner, R.L. (2001) Ann AGNPS: Estimating sediment yield by particle size for sheet \& rill erosion. In: Proceedings of the Seventh Federal Interagency Sedimentation Conference, March 25-29, 2001, Reno, Nevada. vol. 1, Sediment and flow modeling, 1-7.

[5] Kinnell, P.I.A. (2005) AGNPS-UM: Agricultural Non Point Source Pollution Model using the USLE-M. User guide, version 4.02. University of Canberra, Canberra, Australia.

[6] Morgan. R.P.C., Quinton, J.N., Smith, R.E., Govers, G., Poesen, W.A., Auerswald, K., Chisci, G., Torri, D., Styczen, M.E. (1998) The European Soil Erosion Model (EUROSEM): A dynamic approach for predicting sediment transport from fields and small catchments. Earth Surf. Processes Landf.23, 527-544.

[7] Schmidt, J., Von Werner, M., Michael, A. (1999) Application of the EROSION 3D model to the CATSOP watershed, The Netherlands. Catena37, 449-456.

[8] De Roo, A.P.J., Wesseling, C.G., Ritsema, C.J. (1996) LISEM: A singleevent physically based hydrological and soil erosion model for drainage basins. I: Theory, input and output. Hydrol. Processes 10, 1107-1117. 
[9] Flanagan, D.C. (ed.), Nearing, M.A. (ed.) (1995) USDA-Water Erosion Prediction Project (WEPP): Hillslope Profile and Watershed Model Documentation. NSERL Report No. 10, National Soil Erosion Research Laboratory. USDA ARS, West Lafayette, Indiana, USA.

[10] Neitsch, S.L., Arnold, J.G., Kiniry, J.R., Williams, J.R. (2005) Soil and Water Assessment Tool (SWAT). Theoretical Documentation - version 2005. Blackland Research Center, Grassland, Soil and Water Research Laboratory, Agricultural Research Service, Temple, TX, USA.

[11] Velhas, E. (1991) A Bacia Hidrográficado Rio Leça, Estudo Hidroclimatológico. Revista de Faculdade de Letras - Geografia, I Série, Vol. VH, Porto, Portugal.

[12] Wischmeier, W.H. \& Smith, D.D. (1978) Predicting rainfall erosion losses. USDA Agricu. Handbook 537. Agricultural Research Service, Washington, DC, USA.

[13] Renard, K. G., Foster, G. A., Weesies, G. A., McCool, D. K. \& Yoder, D. C. (1997) Predicting soil erosion by water: a guide to conservation planning with the revised universal soil loss equation (RUSLE). USDA Agricul. Handbook 703.Agricultural Research Service, Washington, DC, USA.

[14] Loureiro, N.S. \& Coutinho, M.A. (2001) A new procedure to estimate RUSLE $\mathrm{EI}_{30}$ index, based on monthly rainfall data and applied to the Algarve region, Portugal. J. Hydrol.250, 12-18.

[15] Pimenta, M.T. (1998) Directrizespara a AplicaçãodaEquação Universal de Perda dos Solos em SIG - Factor de Cultura C e Factor de Erodibilidade do Solo K. INAG, Lisbon, Portugal.

[16] Desmet, P.J.J., Govers, G. (1996) A GIS procedure for automatically calculating the USLE LS factor on topographically complex landscape units. Journal of Soil and Water Conservations 51, 427-433.

[17] Moore, I.D., Burch, G.J. (1986) Physical basis of the length slope factor in the universal soil loss equation. Soil Science Society of America Journal, 50, 1294-1298.

[18] Simms, A.D., Woodroffe, C.D., Jones, B.G. (2003) Application of RUSLE for erosion management in a coastal catchment, southern NSW. In: MODSIM 2003: International Congress on Modelling and Simulation, volume 2, Integrative Modelling of Biophysical, Social and Economic Systems for Resource Management Solutions (Townsville, Queensland, Australia, July 14-17), 678-683.

[19] Irvem, A., Topaloglu, F., Uygur, V. (2007) Estimating spatial distribution of soil loss over Seyhan River Basin in Turkey. J. Hydrol.336, 30-37.

[20] Fu, B.J., Zhao, W.W., Chen, L.D., Zhang, Q.J., Lü, Y.H., Gulinck, H., Poesen, J. (2005) Assessment of soil erosion at large watershed scale using RUSLE and GIS: A case study in the Loess Plateau of China. Land Degrad. Dev. 16, 73-85.

[21] Lim, K. J., Sagong, M., Engel, B.A., Tang, Z., Choi, J., Kim, K. (2005) GIS-based sediment assessment tool. Catena 64, 61-80. 